\title{
CONEXÕES ENTRE O JULGAMENTO MORAL E DETERMINANTES BIOLÓGICOS DO COMPORTAMENTO NA GOVERNANÇA CORPORATIVA
}

\author{
CONNECTIONS BETWEEN MORAL JUDGMENT AND BIOLOGICAL DETERMINANTS OF \\ BEHAVIOR IN CORPORATE GOVERNANCE
}

\author{
Roberto Godoy Fernandes \\ Mestre em Administração pelo Centro Universitário das \\ Faculdades Metropolitanas Unidas (FMU) \\ São Paulo, SP - Brasil \\ bob.godoy@gmail.com \\ Eric David Cohen \\ Doutor em Administração pela \\ Fundação Getúlio Vargas (FGV) \\ São Paulo, SP - Brasil \\ ericdcohen@gmail.com
}

Resumo

O presente artigo analisa os comportamentos antissociais ou antiéticos no contexto da Governança Corporativa, pautado pela necessidade de se acompanhar com instrumentos próprios seus efeitos, à luz dos avanços neste campo de conhecimento. Ao preconizar a sua validação adequada, postula-se a necessidade de considerar os diferentes aspectos do comportamento humano quanto aos processos de julgamento. Neste sentido, objetiva-se identificar as conexões teóricas entre o julgamento moral e o comportamento ético organizacional, notando-se uma lacuna em relação às normativas existentes. A metodologia do estudo é descritiva de natureza exploratória, utilizando a abordagem mista qualitativa e quantitativa, iniciando-se com uma pesquisa bibliométrica para identificação de estudos anteriores e da revisão da literatura pertinente ao julgamento moral à luz do comportamento organizacional. Identifica-se na literatura que o julgamento moral do indivíduo é influenciado por fatores genéticos, socioambientais e biossociais, que influenciam o comportamento por meio do julgamento moral. Foram coletados dados utilizando uma escala validada de mensuração desenvolvida por outros autores e adaptada ao contexto local. Não foi possível concluir a respeito das possíveis diferenças de julgamento moral utilitarista no comportamento de profissionais da área comercial. Já em relação à idade, foi confirmada uma tendência ao comportamento deontológico para a amostra de maior idade e uma tendência utilitarista para a amostra masculino. A partir destas evidências, sugerem-se novas hipóteses que são relevantes para o desenvolvimento da teoria neste campo de conhecimento, além de evidenciar a necessidade por parte da Governança Corporativa em criar os seus próprios métodos de validação e políticas adequadas.

Palavras-chave: Governança Corporativa. Ética. Dilemas Morais. Determinantes Biológicos do Comportamento.

\section{Abstract}

This article analyzes antisocial or unethical behavior in the context of Corporate Governance, guided by the need of monitoring its effects with its own instruments, in light of the advances in this field of knowledge. When advocating its proper validation, it is postulated the need to consider the different aspects of human behavior in relation to judgment processes. In this sense, the objective is to identify the theoretical connections between the moral judgment and ethical organizational behavior, verifying a gap in relation to existing regulations. The research's methodology is descriptive of an exploratory nature, using the mixed approach - qualitative and quantitative, starting with a bibliometric research to identify previous researches and review the relevant literature to moral judgment in the light of 
organizational behavior. The literature findings show that the individual's moral judgment is influenced by genetic, socioenvironmental and biosocial factors, which influence behavior through moral judgment. Field data were collected using a validated measurement scale developed by other authors and adapted to the local context. It was not possible to conclude about the possible differences in utilitarian moral judgment in the behavior of professionals in the commercial area. Regarding the age, a trend towards deontological behavior was confirmed for the older sample and a utilitarian trend for the male sample. Based on this evidence, new hypotheses are suggested that are relevant to the development of theory in this field of knowledge, in addition to highlighting the need by Corporate Governance to create their own validation methods and appropriate policies.

Keywords: Corporate Governance. Ethics. Moral Dilemmas. Biological Determinants of Behavior.

\section{Cite como - American Psychological Association (APA)}

Fernandes, R. G., \& Cohen, E.D. (2020, set./dez.) Conexões entre o julgamento moral e determinantes biológicos do comportamento na governança corporativa. Revista de Gestao e Projetos (GeP), 11(3), 155-184. https://doi.org/10.5585/gep.v11i3.18463.

\section{Introdução}

Desde a infância, o ser humano aprende a ajustar o seu comportamento frente às expectativas da sociedade e das leis vigentes. Este processo acaba por se tornar um aprendizado da vida em sociedade, com influências diretas e indiretas que acompanharão o indivíduo por toda a vida (Decety \& Cowell, 2016). A conduta social é algo complexo, em meio a influências diversas, dentre as quais podemos citar as variáveis genéticas, sociais e biossociais, que quando combinadas afetarão o comportamento humano.

A exemplo disto, a cultura traz evidências importantes do que se considera uma conduta imoral, cujos significados dependerão do contexto cultural (Mednick \& Kandel, 1988; Christensen, Flexas, Calabrese, Gut, \& Gomila, 2014; Corvo, 2019).

Para Portnoy et al. (2018), o processo decisório humano trabalha de maneira consciente e inconsciente. Mesmo nas decisões conscientes, considera-se que o ser humano não tem domínio total dos seus processos cognitivos, tais como o raciocínio, aprendizado e memória. Posto de outra maneira, uma parte considerável das nossas ações pode ser explicada pelos processos emocionais, encontrando-se poucos elementos de racionalidade. Neste contexto, é relevante notar os avanços no campo da neurociência, que tem produzido achados importantes nesta nova direção da ciência do comportamento humano. Tais achados vêm descortinando novas teorias e modelos teóricos do comportamento, de forma a elevar a importância dos determinantes biológicos como agentes influenciadores nos processos cognitivos. Nota-se, a este propósito, que as pesquisas mostram que fatores como influência social podem alterar de forma significativa o DNA do indivíduo nos primeiros estágios de vida; assim, as influências recebidas 
aos dois anos de idade produzirão efeitos aos 12 ou aos 20 anos de idade (Portnoy, Legee, Raine, Choy, \& Rudo-Hutt, 2018).

A literatura dá indicações de que o livre arbítrio do ser humano não é tão livre assim, uma vez que está ancorado em variáveis que se entrelaçam com o DNA humano e que são influenciados por determinantes biológicos, por meio de contribuições genéticas, assim como do meio social, das relações humanas, do convívio e do desenvolvimento humano. Cabe ressaltar, que as interações sociais em conjunção com os fatores genéticos e biológicos poderão ser intensas a ponto de produzir alterações no DNA, que transformarão o comportamento levando até mesmo ao comportamento antissocial ou à desonestidade (Portnoy, Legee, Raine, Choy, \& Rudo-Hutt, 2018; Farrington, Kazemian, \& Piquero, 2019).

Para o FBI (2019), os indivíduos desonestos, que incorrem em comportamento de fraude e praticam crimes do colarinho branco, são pessoas comuns. Para Raine (2015), a capacidade destes indivíduos de avaliar a situação e julgar é prejudicada, frente a uma oportunidade tentadora. Ainda para o FBI (2019), o criminologista Edwin Sutherland foi quem primeiro utilizou o termo "Crime do Colarinho Branco", em 1939, no entanto este termo se tornou sinônimo de uma série de fraudes cometidas tanto por empresas, quanto por profissionais do governo.

Nesse ápice, ao considerar que as pesquisas desenvolvidas por meio de ferramentas e conceitos da neurociência, poderão ajudar a identificar os processos decisórios organizacionais, e que tanto o IBGC ou outra normativa não abordem as questões biológicas do comportamento que possam afetar o comportamento moral e por sua vez o comportamento ético organizacional $-\mathrm{a}$ governança corporativa (GC) parte da premissa que todos são iguais e não preconiza tratamento diferenciado para pessoas diferentes, coloca-se a seguinte pergunta de pesquisa: Quais são as conexões teóricas entre os construtos do julgamento moral e determinantes biológicos na formação do comportamento ético organizacional? Essa pergunta de pesquisa busca respostas frente ao olhar consequencialista do comportamento gerencial, visto que outras teorias poderiam colocar - de maneira enviesada - outros modelos teóricos de comportamento que levariam a um risco desnecessário, prejudicando a boa GC. Cabe notar, ainda, que todas estas questões são de difícil avaliação, mas a GC precisa refletir e desenvolver os seus próprios instrumentos de acompanhamento e validação.

Considerando as teorias e conceitos dos dilemas morais e seus efeitos no julgamento moral e no conjunto de princípios morais, esta pesquisa tem por objetivo identificar as conexões teóricas entre o julgamento moral e determinantes biológicos na formação do comportamento ético organizacional. Para alcançar o objetivo geral desta pesquisa, três objetivos específicos são propostos: 1- Por meio da revisão da literatura, identificar o estado da arte dos determinantes biológicos que 
poderão influenciar o comportamento humano;

2- Propor hipóteses relacionadas às conexões entre o julgamento moral e os determinantes biológicos na determinação do comportamento ético organizacional; 3- Avaliar por meio da análise quantitativa o julgamento moral, por meio do emprego de um questionário validado dos dilemas morais.

Quanto aos objetivos deste trabalho, os mesmos possuem duas partes: a primeira parte, atende ao primeiro objetivo especifico, por meio da revisão da literatura, isto inclui a investigação dos determinantes biológicos, e a segunda parte, o ensaio de campo, tem o objetivo de mostrar a análise do comportamento moral que recebe as influencias dos determinantes biológicos, atendendo ao segundo e terceiro objetivo específico. A parte experimental deste trabalho analisa uma amostra formada por dois grupos de indivíduos para comparação: um grupo formado por profissionais da área comercial, e um segundo grupo formado por profissionais de diversas áreas.

Além desta seção introdutória, este artigo é composto por outras quatro seções: referencial teórico, abrangendo a construção dos constructos da pesquisa; metodologia; analise dos resultados; conclusões e considerações finais.

\section{Referencial teórico}

Para atender os objetivos propostos, a revisão da literatura está organizada em quatro subtópicos que visam apresentar os construtos, e relacionar a teoria do julgamento moral e determinantes biológicos com o comportamento ético nas organizações. O primeiro construto contextualiza as questões da GC - conforme estabelecido pelo IBGC, por meio dos pilares e princípios das boas práticas de GC. O segundo construto aborda a ética sob uma perspectiva filosófica, abordando os conceitos da deontologia e da ciência dos deveres, à luz dos direitos e obrigações do ser humano. Já o terceiro construto define o dilema moral e como este é idealizado pelo ser humano. Por fim, são abordados os determinantes biológicos, que se originam a partir dos fatores sociais, ambientais e genéticos e que influenciam o comportamento humano.

\subsection{Governança Corporativa $(G C)$}

Para Tricker (2015), a GC é o sistema pelo qual as empresas deveriam ser administradas. Enquanto a gestão se preocupa com a atividade fim da empresa, a GC garante que os negócios aconteçam de forma honesta e transparente. Segundo Rossetti e Andrade (2016), os conflitos de agência formam a base da GC e são produtos do oportunismo de gestores, quando os acionistas não estão presentes ou quando os direitos de acionistas minoritários são expropriados em virtude das ações oportunistas de acionistas majoritários.

Para Silveira (2010) a GC se caracteriza por uma abordagem multidisciplinar, ao representar a forma com que as sociedades são dirigidas e controladas; em outras palavras, ela se apoia em princípios e regras, explicitas ou 
implícitas. Nesse sentido, os principais atores são: a diretoria, conselho de administração e acionistas. Silva (2018), corrobora esta visão, ao definir que a GC é composta por um conjunto de práticas que têm por objetivo aperfeiçoar a execução das atividades das organizações, protegendo investidores, empregados e credores. Em contrapartida, Rossetti e Andrade (2016) postulam que a GC não pode ser reduzida a uma única definição, uma vez que ela incorpora diversas interpretações e conceitos, que podem variar de país para país.

À luz da pergunta de pesquisa - qual seja, identificar as conexões teóricas entre o julgamento moral e os determinantes biológicos na formação do comportamento ético organizacional, torna-se necessário explorar o princípio da transparência e o pilar da conduta e conflito de interesses através do conceito de culpabilidade do indivíduo.

O princípio da transparência diz respeito ao processo estruturado de divulgação de todas as informações inerentes aos negócios que sejam de interesse dos diversos stakeholders no processo decisório do negócio; estes podem ser acionistas maioritários, minoritários e interessados no desenvolvimento sustentável da organização (IBGC， 2015; IBGC, 2017). Para Bizerra, Alves e Ribeiro (2012), os princípios da Transparência e da Prestação de Contas são essenciais às organizações públicas e privadas. Os códigos de boas práticas de GC são desenvolvidos com base nestes princípios, para permitir o controle social e a avaliação correta dos resultados empresariais. Segundo Egorov et al. (2015), a transparência é essencial nos negócios modernos e é preconizada pela regulamentação, a partir de tratados e leis internacionais. Por meio delas, a publicação de dados empresariais permite a divulgação do estado real do negócio.

Ainda que a observância das leis não seja o objetivo deste estudo, cabe reforçar que no Brasil há um conjunto de leis, decretos e deliberações que abordam a questão da transparência, tanto no âmbito público, como nas companhias abertas. A seguir, relaciona-se as principais leis, decretos e liberações em vigor que tem por objetivo delimitar o comportamento esperado dos dirigentes e demais stakeholders: CVM 586/2017 (CVM, 2009); Lei No 12.527/2011 (Brasil, 2011); Lei Complementar No 131/2009 (Brasil, 2009); CVM 480/2009 (CVM, 2009); CVM 560/2008 (CVM, 2008). De forma irrevogável, as leis, regimentos e códigos de conduta devem ser seguidos, sendo que, nenhuma infração ou desvio seja tolerado (IBGC, 2017).

Vale notar que os atos de natureza ilícita, antiética e fraudulenta precisam ser prevenidos, identificados e tratados por meio do emprego de políticas especificas. (IBGC, 2015). De acordo com o Código Civil, artigo 186 Título III / Dos atos Ilícitos, define-se o ato ilícito como sendo: “[...] ação ou omissão voluntária, negligência ou imperícia, violar direito ou causar prejuízo a outrem" (Brasil, 2002). 
O conceito da culpabilidade, à luz do Código Penal, postula que o agente responderá pelo delito na circunstância em que comete a ação, com dolo ou culpa. As ações do agente deverão apresentar uma motivação ou intenção, um efeito, e uma finalidade. A motivação da ação define o dolo, se houver. O artigo 18 Título II / Do Crime da lei 7.209/1984, preconiza duas classificações, quais sejam: dolo direto e indireto (ou eventual). $\mathrm{Na}$ ação dolosa direta, há intenção de cometer a infração, uma vez que o dolo deriva da consciência do agente, e sua conduta pode estar associada a um ato delituoso. Já na ação dolosa indireta, assume-se o risco que for produzido pela ação (Brasil, 1984).

Por outro lado, na ação culposa pode haver negligência, imperícia ou imprudência. $\mathrm{O}$ Código Penal postula que a ação do agente mesmo se voluntária - não objetivava tal resultado. A negligência refere-se ao deixar de fazer o que era necessário, mesmo se desconhecido. Já a imperícia diz respeito ao desconhecimento para o desempenho de algo necessário, e a imprudência está associada a uma conduta arriscada, perigosa e precipitada (Brasil, 1984; Picon, 2015).

Segundo Greco (2015), frente ao suporte fático e à consequência jurídica, o artigo 59 estipula que a conduta social e a personalidade do agente constituem critérios de reprovação e prevenção do crime (Brasil, 1984). Já a personalidade do agente não pode ser considerada para aplicar a sanção prevista na norma, pois tal conceito é derivado de outras ciências sociais. Em conclusão, Greco (2015), postula que a decisão do Juiz não deve passar pela personalidade do agente, pois tal análise demandaria uma construção mais aprofundada de todo o período de sua vida, a começar pela infância.

\section{2 Ética}

$A$ ética e a moral possuem conceitos complementares; contudo, diferem em seus princípios. A palavra ética é derivada do grego Ethos, que significa morada, lugar que vivemos, mas na contemporaneidade passou a significar caráter ou modo de ser que uma pessoa ou um grupo adquire ao longo da vida. Portanto, ela está associada aos conceitos da cultura e da educação, na busca de uma sociedade justa. Já a palavra moral deriva do latim Mores ou Morus, que está relacionada aos usos e costumes no contexto do comportamento em sociedade - ou seja, de se fazer o bem, ou o mal.

Kant preconiza que a moral não é uma doutrina, e sim o proceder que torna o indivíduo digno da felicidade (Pedrosa, 2015). Pedrosa (2015, p. 28), ainda defini: "Chamamos de Ética o conjunto de coisas que as pessoas fazem quando todos estão olhando. $\mathrm{O}$ conjunto de coisas que as pessoas fazem quando ninguém está olhando chamamos de Caráter".

\section{Todorov (2013), preconiza que o} comportamento é objeto de estudo do campo da psicologia. Ele considera que a pesquisa nesta área vai além das interações entre o indivíduo e o ambiente. Em outras palavras, para este autor, as diversas interações compõem um processo 
complexo envolto em estímulos e respostas interdependentes. Nesta linha, o comportamento dependerá de várias atividades subjacentes ao indivíduo, em associação com o ambiente. Gouveia (2015), corrobora este entendimento, ao considerar que o comportamento sofre alterações no tempo, como resposta aos impactos culturais e mudanças sociais em etapas que têm começo, meio e fim. Já o caráter não possui uma única definição universalmente aceita pela academia. Caráter e personalidade são termos semelhantes e intercambiáveis. O caráter pessoal pode ser entendido como a maneira habitual de agir, em função de um conjunto de traços individuais de personalidade e de ordem moral, que levam o indivíduo a adotar ações - sejam elas boas ou más (Baumgarten, 1954).

Vale notar que os valores morais versam sobre a qualidade das relações humanas. Tal discussão é permeada por um conjunto de princípios e diretrizes, seguidos de forma livre e espontânea, que estabelecem a conduta individual, social e organizacional. De maneira distinta a ética e moral dependerão do país, da cultura, do pertencimento aos grupos sociais, das transferências familiares, e dos valores (Oliveira, Medeiros, Silva, \& Lucas, 2016). Em um estudo anterior, Ashley (2005), já postulava que a adoção da ação moral não é por imposição, pois quem as prática considera que é correto e desejável agir com ações morais. Por fim, Durkheim (2012), postulou que a moral tem cunho restritivo, com objetivos específicos e demarcados que determinam a atividade individual. Segundo este autor, a moral deve conduzir a forma de agir da sociedade.

\subsubsection{O fundamento do utilitarismo}

Para Bentham e Mill Oliveira (2015), a lei moral estabelecida pelo Utilitarismo, preconiza que a felicidade ou o interesse de qualquer indivíduo esteja em harmonia com o todo. $\mathrm{O}$ entendimento por felicidade pode ser classificado como prazer ou ausência de dor, e que a felicidade ou infelicidade são os únicos fins considerados nessa filosofia (Mill, 2005). Para Mill (2005), o Utilitarismo está organizado em duas frentes filosóficas: Empirismo e Associacionismo. O Empirismo trata que o conhecimento do indivíduo se baseia em dados dos sentidos ou na experiência, isto é, o raciocínio puro, considera ainda que sem as devidas experiências, o indivíduo não alcançará o conhecimento pleno. Já o associacionismo, preconiza sobre os mecanismos de funcionamento da mente humana, e trata da associação entre os experimentos e ideias do indivíduo.

Mill (2005), define que a felicidade do próprio agente não seja o guia ou seu auge, e sim a felicidade de todos aqueles que possam ser impactados ou beneficiados pela influência de sua conduta, isto é, o Utilitarismo exige imparcialidade: "[...] o utilitarismo exige que ele seja tão estritamente imparcial como um espectador benevolente e desinteressado" (Mill, 2005, p. 58). 


\subsubsection{O fundamento da Deontologia}

Conforme Crockett (2018), enquanto o fundamento do Utilitarismo preconiza que a avaliação das ações do indivíduo deva ser pelos resultados - se desconsidera a intenção, o fundamento da Deontologia define que sua avaliação ocorre por meio de suas ações. Em sua essência, o modelo do Utilitarismo elege suas ações com base em suas consequências, já o modelo da Deontologia, não considera modelos, uma vez que sua referência será a moralidade da ação. Ainda conforme a autora, os achados mostram que o julgamento moral Deontológico resulta do processo decisório espontâneo e automático - do inconsciente. Já o julgamento moral Utilitarista resulta do processo decisório cognitivo - do consciente.

Corroborando, Barbieri e Pilati (2018), definem que a lógica Deontológica considera o certo e errado para a tomada de decisão, agindo de forma automática, enquanto a lógica Utilitarista analisa as consequências em cada contexto, agindo de forma controlada. Contrapondo a questão da emocionalidade no julgamento Deontológico, um estudo anterior, conforme Elqayam et al. (2017), preconizam que o cérebro humano ao realizar o julgamento moral Deontológico, faz uso de processos intuitivos com alto grau emocional, e baixo processamento, enquanto o julgamento moral Utilitarista, faz uso de processos analíticos com alto processamento.
2.2.3 Utilitarismo ou Deontologia: o que é melhor para os negócios?

Para Staveren (2007), a Deontologia apresenta melhores resultados na análise ética na economia se comparado com o Utilitarismo, contudo a Deontologia possui fraquezas que hipoteticamente seriam solucionadas com o emprego de uma nova teoria ética, a teoria da Ética da Virtude. Para essa autora, a Ética da Virtude define que haja a inter-relação dos indivíduos e o comprometimento com os valores compartilhados, valores estes que vão além daqueles estabelecidos pela sociedade. Nesse sentido, a Ética da Virtude preconiza que o comportamento moral não deve ocorrer por meio de uma escolha ou por receio da punição, isto é, deve ocorrer por meio de práticas nas quais os indivíduos estejam correlacionados na busca pelo valor agregado. Corroborando, Sison, Ferrero e Guitián (2018), definem que a Ética da Virtude é mais adequada, uma vez que esta unifica as fundamentações Deontológica e Utilitarista. Nesta continuidade, a Ética da Virtude está centrada no indivíduo e impõe um modelo que faz a seguinte pergunta: "Que tipo de pessoa me torno ao executar esta ação?" Nesta significação, essa nova abordagem interrelaciona as consequências provenientes do Utilitarismo, contudo em concordância com as normas, padrões morais e deveres preconizados na Deontologia - cria-se uma forma holística entre indivíduos e suas ações.

De acordo com Micewski e Troy (2007), a Deontologia é o caminho adequado para os negócios, isto é, os princípios 
Deontológicos devem orientar a tomada de decisões dos profissionais. Nesse sentido, dever-se-ia criar mecanismos de autorregularão de suporte as organizações que orientassem os profissionais no caminho do comportamento moral e mitigassem os comportamentos antiéticos identificados por posturas Utilitaristas.

Asanuma (2010), define que a moralidade das ações, presente na abordagem da Deontologia, está relacionada com o sucesso dos negócios. Os achados do estudo deste autor, mostram que na intenção de potencializar os lucros, se houver comportamentos antiéticos e/ou a exclusão de obrigações morais, estes, geram tensão entre os negócios e a ética e reduzem as chances de sucesso nos negócios. Outro achado nesse mesmo estudo mostra que, em si, o emprego da ética Deontológica permite maior estabilidade na tomada de decisões, nesse sentido, indivíduos Deontológicos tem menos chance de alterar as suas decisões ao se depararem com situações que envolvam riscos percebidos, enquanto indivíduos Utilitaristas têm mais chance de mudar suas decisões.

$$
\text { Para Crockett (2018), ambos }
$$

contribuem com suas vantagens para a administração. Enquanto o Utilitarismo apresenta vantagens para as decisões simples na visão de potencializar o bem e minimizar o mal, por sua vez, a Deontologia oferece vantagens na resolução de problemas complexos, incertos e/ou ambíguos. Em última análise, o comportamento moral Deontológico ajuda o indivíduo a se afastar de problemas.

\subsection{Dilemas morais}

$\mathrm{Na}$ literatura, os dilemas morais têm se apresentado como um importante instrumento de análise e entendimento do julgamento moral (Fernandes, et al., 2018). Para Christensen et al. (2014), os dilemas morais são constituídos por pequenas histórias que descrevem uma situação, e apresentam razões morais relevantes, porém conflitantes. Estes autores definem que as situações apresentadas nos dilemas, trazem o dever de não matar ou o de causar danos, em conflito ao dever de ajudar, no qual o participante se torna protagonista da história do dilema.

Para Bostyn et al. (2018), os dilemas morais permitem investigar a tensão entre a ética Utilitarista - também conhecida como consequencialista, e a ética Deontológica também conhecida como legalista. Nesse contexto, os fatores morais individuais sofrem influências que podem ser classificadas em experiências genéticas - ou biológicas, sociais e biossociais, como, por exemplo: familiares, religiosas e educacionais (Mednick \& Kandel, 1988; Christensen, Flexas, Calabrese, Gut, \& Gomila, 2014; Corvo, 2019).

Neste contexto, se reforça a importância dos dilemas morais apresentados no experimento - os dilemas permitem avaliar o comportamento do indivíduo, distinguindo-o de Utilitarista ou Deontológico. Cabe explicar que os dilemas morais precisam ser bem planejados e os fatores potencialmente relevantes a pesquisa, precisam ser controlados, com situações que sigam a diretiva do estudo em 
Christensen et al. (2014). Estes autores analisaram os dilemas morais e apresentaram quatro principais fatores de controle dos dilemas morais, quais sejam: Força Pessoal, Beneficiário - quem recebeu o benefício, Evitabilidade - se a morte pode ser evitada e a Intencionalidade, ou seja, se o dano verificado é instrumento da pesquisa, ou se foi um efeito colateral não desejado (Moore, Clark, \& Kane, 2008).

\subsubsection{Utilitarismo e Deontologia}

A partir das contribuições de Christensen et al. (2014), considera-se que, na apresentação do dilema moral, a ação que o indivíduo possa ou não cometer é compreendida como transgressão moral ou violação moral. Nesse contexto, haverá duas opções; no primeiro caso, o protagonista comete a ação. Já na segunda situação, ele se omite perante o contexto apresentado.

Para diversos autores, a transgressão ou violação moral é uma forma de julgamento moral, que pode ser classificado como Utilitarista ou Deontológico (Greene, Sommerville, Nystrom, Darley, \& Cohen, 2001; Christensen \& Gomila, 2012). De acordo com Gawronski e Beer (2017), a distinção entre o Utilitarismo e a Deontologia leva a uma diferente estrutura conceitual do julgamento moral no conhecimento científico. Segundo a perspectiva Utilitarista, a moralidade da ação depende dos resultados que visam o bem para o maior número possível de pessoas. Em contrapartida, a Deontologia (legalismo), preconiza que a moralidade da ação depende de sua consistência com as normas morais - como, por exemplo, o dever de não matar.

\subsubsection{Dilemas morais pessoais e impessoais}

Para Greene et al. (2001) e Greene et al. (2004), os dilemas morais levam a duas formas de ação por parte do protagonista: a ação pessoal e a ação impessoal. No primeiro caso, o protagonista necessariamente realiza uma ação. Já no segundo caso, o protagonista apenas inicia uma ação que levará ao dano. Vale mencionar que os dilemas morais de ordem pessoal poderão induzir ao julgamento Deontológico por ativação emocional, ao passo que os dilemas morais impessoais poderão induzir a julgamentos Utilitaristas e racionais (Christensen, Flexas, Calabrese, Gut, \& Gomila, 2014; Fernandes, et al., 2018).

\subsubsection{O julgamento moral ao longo da idade}

Analisando possíveis diferenças no processo de tomada de decisão, o estudo de Worthy et al. (2011), comparou duas amostras com faixas etárias diferentes. A primeira amostra, considerada madura, era formada por indivíduos com idade entre 60 a 84 anos, e a segunda amostra, considerada jovem, era formada por indivíduos entre 18 e 23 . Os achados mostram que a amostra madura possui melhor capacidade analítica em contextos em que foi preciso aprender com as escolhas realizadas anteriormente, para servirem de base para decisões futuras. Este estudo mostra que pessoas mais velhas possuem melhor aprendizado holístico, e não toma por base no 
seu processo decisório somente o resultado das ações.

Para Bruin, Parker e Fischhoff (2012), algumas capacidades acerca da tomada de decisão diminuem com o aumento da idade, enquanto outras permanecem as mesmas ou até mesmo são aprimoradas. À exemplo disso, os achados mostram que as capacidades de cognição representadas por meio do raciocínio e resolução de problemas sofrem diminuição com o aumento da idade, contudo se verifica que em tarefas que é preciso experiência e uso de padrões anteriores, o desempenho é no mínimo o mesmo se comparado a amostra formada por jovens. Corroborando, Sparrow e Spaniol (2016), mostram que as estruturas do cérebro são afetadas com o aumento da idade, isto porque seu volume diminui, há a redução dos tratos brancos pelo envelhecimento normal - isto implica diretamente nos córtices frontal e dorsolateral, que são essenciais para o desempenho de funções executivas. Ainda que haja tais reduções cognitivas, cabe lembrar que os autores reforçam empiricamente que de forma geral a cognição reduzida - dentro de seus limites normais - não afetam o processo da tomada de decisão e aversão aos riscos. Nesse ápice, com o aumento da idade os achados mostram um melhor desempenho no estratégico, uma vez que não há redução dos fatores como a aversão aos riscos, mas há o aumento na capacidade em adiar recompensas, gerir melhor mudanças motivacionais capazes de avaliar os resultados das decisões, bem como na capacidade de escolher melhor as estratégias de decisão.

2.3.4 O julgamento moral em homens e mulheres e as organizações

O estudo de Arutyunova, Alexandrov e Hauser (2016) reacende a questão de que as normas sociais são categorizadas em explícitas e implícitas; conjuntamente aos processos cognitivos, variam de acordo com a cultura, e por meio de um processo social eles influenciam o julgamento moral. Desta forma, as influências ocorreram de maneira diferente em cada estágio da vida, sofrendo a influência das normas e expectativas sociais. Os achados deste estudo retratam que o homem possui tendência mais Utilitarista do que a mulher; supõe-se que tal diferença seja decorrente da maior emocionalidade nas relações interpessoais das mulheres. Por outro lado, outros estudos que utilizaram cenários e metodologias similares dão indicações de que o sexo, idade, afiliação política e crença religiosa não conseguem explicar de forma significativa as diferenças de comportamento. Contudo, argumentam que as decisões Utilitaristas estariam diretamente associadas com processos cognitivos racionais e deliberativos, reduzindo a emoção e a empatia, e especulam que a resposta pode estar no processo de socialização na idade infantil (Greene, Morelli, Lowenberg, Nystrom, \& Cohen, 2008; Arutyunova, Alexandrov, \& Hauser, 2016). Contribuindo com este entendimento, estes autores mencionam estudos por imagem do cérebro (fMRI) que apontam que as mulheres 
apresentam diferenças na ação moral. Já no quesito idade, os exames de neuroimagem mostram que há diferenças na hemodinâmica cerebral na amostra com idades entre 13 e 53 anos, ao avaliar imagens com e sem transgressões morais.

Já o estudo de Zalata et al. (2018) reuniu e analisou os relatórios financeiros de empresas no período compreendido entre 19922014; os autores relatam que após a aprovação da lei Sarbanes-Oxley (SOX) em 2002, as CEOs do sexo feminino demonstraram maior propensão ao comportamento ético na comparação com seus colegas do sexo masculino. Enquanto a prática de ações nãoéticas de CEOs do sexo feminino decrescia, o mesmo não se verificava com os dados coletados dos CEOs do sexo masculino; há indícios de que este comportamento não está relacionado com a sensibilidade a ética, e sim com a aversão ao risco. Anteriormente a esse estudo, Raine (2015) já postulava que as mulheres cometem menos crimes, são menos antissociais, se preocupam mais com sua própria saúde, evitam danos físicos, e possuem processamento cognitivo superior na comparação com os homens. Os achados de Denson et al. (2018) corroboram com Raine (2015), contudo acrescentam novos achados, tais como o descreve que as provocações são situações com alto potencial de aproximar o comportamento violento na mulher, se comparado ao do homem, e que o risco também aumenta nas relações amorosas. À exemplo de mulheres cometerem menos crimes, a análise dos dados prisionais de indivíduos sentenciados a morte nos Estados Unidos, mostra que menos de $2 \%$ de todos os condenados e executados na história prisional norte-americana foram mulheres, dados extraídos diretamente do DPIC (2019).

Ora navegando nos dilemas morais na GC, o estudo de Schwepker Jr. e Good (2011), analisou o comportamento de profissionais de vendas e do impacto nos negócios em empresas business-to-business. Estes autores postulam que o julgamento moral dos vendedores não está significativamente relacionado com os resultados; contudo, está associado de forma significativa com o desempenho comportamental. Para eles, os profissionais de vendas que fazem julgamentos mais éticos têm mais chance de realizar vendas e colocar o foco nas necessidades do cliente, com melhor desempenho comportamental.

Nesta mesma linha, Ojikutu, Obalola e Omoteso (2013), postulam que o comportamento ético pode ser institucionalizado nas organizações desde que haja apoio da alta direção, por meio de um sistema de punições e recompensas. Ao analisar a questão do julgamento moral, os autores dão indicação de que os valores éticos corporativos e as crenças pessoais dos gerentes têm um papel fundamental na correção e na prevenção de atos antiéticos. Contudo, quando as metas dos vendedores forem muito elevadas, ou seja, difíceis de alcançar, haverá um aumento da tendência de comportamento antiético. 
Já no âmbito empresarial, o estudo de Chen (2019), mostra que a competição aumenta a responsabilidade deontológica. Este estudo comparou o comportamento do julgamento moral Utilitarista e Deontológico em dois grupos de trabalhadores: um pago a salário fixo, e outro pago por resultados. Os achados apontam que os trabalhadores pagos a salário fixo são mais Deontológicos se comparados aos trabalhadores que recebem em função do resultado, e que a preocupação em relação ao comportamento competitivo é proporcional à renda.

\subsection{Determinantes biológicos do comportamento}

Ao se estudar quais são as partes do cérebro que estão diretamente relacionadas com o processo decisório moral, os pesquisadores Healey, Hodgkinson e Massaro (2018), avaliaram se seria possível que o cérebro tomasse decisões sem a interação do corpo, de forma autônoma. Os achados deste estudo revelam que esta hipótese foi rejeitada, uma vez que o cérebro humano toma decisões interagindo intensamente com o corpo. Esta pesquisa foi realizada num ambiente empresarial que avaliou os comportamentos de ordem interpessoal e social.

Diversos estudos concordam que não há um único circuito cerebral responsável pelo processamento das decisões morais. Entre estes estudos e achados, estão as pesquisas de (Pascual, Rodrigues, \& Gallardo-Pujol, 2013; Decety \& Cowell, 2016; Cuñat-Agut, MartíVilar, \& Suay I, 2016; Fernandes, et al., 2018).
Para Pascual, Rodrigues e Gallardo-Pujol (2013), e Decety e Cowell (2016), as regiões e suas subáreas cerebral envolvidas no processo decisório moral envolvem os lobos: frontal, parietal, temporal, límbico e estruturas subcorticais. Os Quadros 1, 2 e 3, apresentam um resumo ao relacionar estas regiões cerebral com suas influências no processo comportamental e decisório moral.

De acordo com os achados mostrados nos Quadros 1, 2 e 3, as áreas que compõe o Córtex Pré-Frontal, tem papel vital na caracterização do comportamento dorsolateral, ventrolateral, orbitofrontal, cingulado e giro medial. Estes achados mostram que o pleno funcionamento destas áreas contribui para um comportamento de melhor controle executivo, e por sua vez, com melhor desempenho no processamento moral. Contudo, o inverso tem suas consequências, haja visto que, lesões, disfunções ou deficiências severas, tais como a ausência de uma área crítica - por meio de necessidade cirúrgica, pode impactar de forma negativa na teoria da mente e no processo decisório moral. Ainda com base nos autores dos Quadros 1, 2 e 3, os achados apontam que as posturas comportamentais humanas sofrem alterações como: da teoria da mente, tomada de decisões, de ordem cognitiva, de valores morais - valores, conflitos e julgamento, de autocontrole, e de interpretação e compreensão dos pensamentos e estados mentais de si mesmo e dos outros, uma vez que a própria teoria da mente preconiza que a mentalização representada no indivíduo e em 
outros trata dos estados mentais, tais como: crença, intenção, desejo e consciência. Nesse sentido, assegura-se que deficiências, inabilidades e inflexibilidades nas posturas, tais como: perseverança, controle emocional de respostas apropriadas, evitabilidade a punição consequencialista dos atos, impulsividade, controle e percepção da inibição da realização de atos, e resolução de conflitos podem ter sua natureza baseadas nas ineficiências do cérebro.

Nesse ponto, cabe reforçar que este estudo não é da área da saúde, e que os aspectos biológicos levantados e discutidos, foram concebidos para alicerçar o entendimento e atendimento ao objetivo central desta pesquisa.
Frente as questões relacionadas ao Julgamento Moral e aos Determinantes Biológicos, a literatura dá indicações de que quando o indivíduo sofre maus tratos e privações na infância, há uma maior probabilidade de ocorrência de danos cerebral, inclusive junto ao córtex temporal. Tais danos poderão levar ao desvio de comportamento, produzir influências negativas na tomada de decisão, levar à insensibilidade emocional, falta de empatia e comportamento desinibido, ou mesmo ao comportamento antissocial (Fernandes, et al., 2018). O Quadro 1 apresenta a relação entre a região cerebral e sua influência comportamental no processo decisório.

Quadro 1 - Relação entre a Região Cerebral e Sua Influência no Processo Decisório Moral

\begin{tabular}{|c|c|c|}
\hline $\begin{array}{l}\text { Região } \\
\text { Principal }\end{array}$ & Subárea & Influência Comportamental \\
\hline \multirow[t]{5}{*}{$\begin{array}{l}\text { Lobo } \\
\text { Frontal }\end{array}$} & $\begin{array}{l}\text { Córtex Pré- } \\
\text { frontal } \\
\text { Ventromedial }\end{array}$ & $\begin{array}{l}\text { - Comportamento do julgamento moral e tomada de decisões, pela combinação de } \\
\text { processos cognitivos e emocionais, destinados a orientar o comportamento social } \\
\text { - Lesões nesta subárea aumentam significativamente as chances de respostas } \\
\text { utilitárias a dilemas morais pessoais de conflito alto, e de representar as } \\
\text { consequências abstratas de suas decisões } \\
\text { - O lado esquerdo mostra maior ativação em indivíduos com menor competência } \\
\text { de julgamento moral ao identificar violações de normas }\end{array}$ \\
\hline & $\begin{array}{l}\text { Córtex } \\
\text { Orbitofrontal }\end{array}$ & $\begin{array}{l}\text { - Atua nos valores morais, relacionando recompensas e punições } \\
\text { - Envolvido na solução de problemas que envolvem principalmente valores morais } \\
\text { elevados }\end{array}$ \\
\hline & $\begin{array}{l}\text { Córtex Pré- } \\
\text { frontal } \\
\text { Dorsolateral }\end{array}$ & $\begin{array}{l}\text { - Atua no autocontrole, inteligência, bem como no comportamento Utilitarista, } \\
\text { controle cognitivo, solução de problemas, situações baseadas em regras e } \\
\text { comportamento mentiroso }\end{array}$ \\
\hline & $\begin{array}{l}\text { Córtex } \\
\text { Cingulado } \\
\text { Anterior }\end{array}$ & $\begin{array}{l}\text { - Atua na detecção de erros, comportamento Utilitarista, tarefas auto referenciais, } \\
\text { teoria da mente e conflito moral } \\
\text { - Atua nas respostas Utilitaristas }\end{array}$ \\
\hline & $\begin{array}{l}\text { Giro Frontal } \\
\text { Medial }\end{array}$ & $\begin{array}{l}\text { - Influência na teoria da mente (estados mentais pessoais e dos outros), e funções } \\
\text { sociais relevantes ao julgamento moral } \\
\text { - Desempenha um papel importante na interpretação e compreensão dos } \\
\text { pensamentos e estados mentais pessoais e dos outros }\end{array}$ \\
\hline
\end{tabular}

Fonte: Adaptado de (Pascual, Rodrigues, \& Gallardo-Pujol, 2013; Decety \& Cowell, 2016).

Para os autores Kahane et al. (2015) e

Fernandes et al. (2018), apesar dos esforços das pesquisas que buscaram relacionar os julgamentos morais Utilitaristas com as 
preocupações genuínas pelo bem estar geral, os resultados até hoje apresentados não podem ser considerados conclusivos.

Buscando compreender os achados biológicos aplicados no mundo empresarial, Kahane et al. (2015) apresentam dois achados importantes na cadeia de eventos que leva ao comportamento Utilitarista: 1 - no ambiente dos negócios, o julgamento Utilitarista associou a perspectiva imoral com transgressões éticas e psicopatia; 2 - o julgamento Utilitarista associou o egoísmo racional com empatia reduzida e sentimento reduzido de identificação com a humanidade. Este último efeito foi analisado por Moll et al. (2018), e relacionou o apego e o pertencimento com ativações no cérebro - que também foram notadas nas mães, quando cuidam dos filhos. O Quadro 2 dá continuidade na apresentação da relação entre a região cerebral e sua influência comportamental no processo decisório.

Quadro 2 - Continuação: Relação entre a Região Cerebral e Sua Influência no Processo Decisório Moral

\begin{tabular}{|c|c|c|}
\hline $\begin{array}{l}\text { Região } \\
\text { Principal }\end{array}$ & Subárea & Influência Comportamental \\
\hline \multirow[t]{3}{*}{$\begin{array}{l}\text { Lobo } \\
\text { Parietal }\end{array}$} & $\begin{array}{l}\text { Região Inferior do } \\
\text { Lobo Parietal }\end{array}$ & $\begin{array}{l}\text { Memória de trabalho, e processamento moral, devido ao envolvimento e controle } \\
\text { cognitivo }\end{array}$ \\
\hline & $\begin{array}{l}\text { Sulco Temporal } \\
\text { Superior }\end{array}$ & $\begin{array}{l}\text { Em conjunto com a região inferior do lobo parietal, atua na percepção e } \\
\text { representação da informação social, que pode ser inferida sobre as crenças dos outros e } \\
\text { suas intenções, bem como na representação da personalidade }\end{array}$ \\
\hline & $\begin{array}{l}\text { Junção Temporo- } \\
\text { parietal }\end{array}$ & $\begin{array}{l}\text { Atua na intuição moral e na atribuição de crenças durante o processamento moral de } \\
\text { outras pessoas, bem como está associado na codificação de crenças e na relação ação e } \\
\text { resultado } \\
\text { Atua quando há a análise de intenções sociais anteriores e atuais } \\
\text { Atua na mentira } \\
\text { Lesões nesta área afetam o julgamento moral }\end{array}$ \\
\hline \multirow[t]{4}{*}{$\begin{array}{l}\text { Lobo } \\
\text { Temporal }\end{array}$} & $\begin{array}{l}\text { Lobo } \\
\text { Temporal }\end{array}$ & $\begin{array}{l}\text { Principal área recrutada na teoria da mente } \\
\text { Lesões ou disfunções tem sido relacionada a psicopatia }\end{array}$ \\
\hline & $\begin{array}{l}\text { Sulco Temporal } \\
\text { Superior }\end{array}$ & $\begin{array}{l}\text { Principal subárea envolvida no julgamento moral } \\
\text { Local inicial da percepção e cognição social, e processamento social } \\
\text { Principal região na interpretação de dilemas morais, com maior ativação nos dilemas } \\
\text { pessoais, e das intenções e crenças dos outros }\end{array}$ \\
\hline & $\begin{array}{l}\text { Sulco Temporal } \\
\text { Posterior }\end{array}$ & $\begin{array}{l}\text { Atua com mais frequência durante dilemas Utilitaristas } \\
\text { Mais recrutado em comportamentos de baixo julgamento moral } \\
\text { Maior ativação ao identificar violações a normas }\end{array}$ \\
\hline & $\begin{array}{l}\text { Giro Angular } \\
\text { Anterior/Médio }\end{array}$ & Atua no julgamento moral, e na avaliação dos dilemas morais pessoais \\
\hline
\end{tabular}

Fonte: Adaptado de (Pascual, Rodrigues, \& Gallardo-Pujol, 2013; Decety \& Cowell, 2016). 
O Quadro 3 finaliza a apresentação da relação entre a região cerebral e sua influência comportamental no processo decisório.

Quadro 3 - Continuação: Relação entre a Região Cerebral e Sua Influência no Processo Decisório Moral

\begin{tabular}{|c|c|c|}
\hline $\begin{array}{c}\text { Região } \\
\text { Principal }\end{array}$ & Subárea & Influência Comportamental \\
\hline \multirow[t]{2}{*}{$\begin{array}{l}\text { Lobo } \\
\text { Límbico }\end{array}$} & $\begin{array}{l}\text { Córtex } \\
\text { Cingulado } \\
\text { Posterior }\end{array}$ & $\begin{array}{l}\text { - Atua em tarefas morais e na experienciação de sentimentos de desgosto } \\
\text { - Atua na memória pessoal, autoconsciência e estímulos emocionais } \\
\text { elevados/relevantes } \\
\text { - Maior atuação em dilemas morais pessoais do que nos impessoais } \\
\text { - Atuação relacionada à: capacidade social, empatia e perdão }\end{array}$ \\
\hline & $\begin{array}{l}\text { Córtex Insular } \\
\text { e Córtex } \\
\text { Insular } \\
\text { Anterior }\end{array}$ & $\begin{array}{l}\text { - Atua em tarefas morais, regulação e processamento emocional } \\
\text { - Atua na consciência que o corpo sente nas situações, incluindo as de risco } \\
\text { - Atua na regulação emocional da empatia, mas também é ativada em } \\
\text { sentimentos de raiva e indignação } \\
\text { - Em jovens, atua na tristeza empática e na percepção de desigualdade } \\
\text { - Atua na percepção e processamento de incertezas, bem como na percepção de } \\
\text { desigualdades } \\
\text { - Atua na percepção e avaliação da dor de outros }\end{array}$ \\
\hline \multirow[t]{4}{*}{$\begin{array}{l}\text { Estruturas } \\
\text { Sub- } \\
\text { corticais }\end{array}$} & Hipocampo & $\begin{array}{l}\text { - Atua no medo condicionado, bem como desempenha um papel importante nas } \\
\text { reações emocionais, isto inclui as expressões faciais, e o processamento auto } \\
\text { relacionado durante as emoções sociais }\end{array}$ \\
\hline & Amigdala & $\begin{array}{l}\text { - Estrutura necessária ao aprendizado moral } \\
\text { - Atua nas reações das emoções, seja por estímulos positivos ou negativos } \\
\text { - Atua na avaliação de julgamentos morais e na tristeza empática em cenários } \\
\text { moralmente relevantes } \\
\text { - Sua disfunção implica em déficits afetivos na psicopatia }\end{array}$ \\
\hline & Tálamo & $\begin{array}{l}\text { - Atua na classificação da tristeza empática e na percepção e avaliação da dor } \\
\text { - O Tálamo é recrutado em situações onde há o dilema de escolher entre seguir } \\
\text { uma regra moral ou um desejo pessoal }\end{array}$ \\
\hline & Septo & $\begin{array}{l}\text { - Atua em comportamentos de caridade, e durante a punição altruísta e durante a } \\
\text { avaliação de estímulos moralmente relevantes } \\
\text { - Disfunção associada a psicopatia }\end{array}$ \\
\hline
\end{tabular}

Fonte: Adaptado de (Pascual, Rodrigues, \& Gallardo-Pujol, 2013; Decety \& Cowell, 2016).

Há evidencias que sugerem que há diferença significativa de comportamento moral entre grupos. Schwepker Jr. e Good (2011), desvinculam os resultados financeiros, mas associam o desempenho comportamental. Já Ojikutu, Obalola e Omoteso (2013), sugerem que os processos organizacionais têm papel vital na formação do comportamento moral da área comercial. Nesse sentido, se mostra relevante testar as seguintes hipóteses:
H1 - Existe diferença entre o comportamento moral do grupo formado por profissionais da área comercial, se comparado ao grupo formado por profissionais de outras áreas - independentemente do sexo.

O estudo de Arutyunova, Alexandrov e Hauser (2016), sugere que o homem possui tendência mais Utilitarista se comparado ao comportamento feminino, e isto pode decorrer da emocionalidade feminina nas relações 
interpessoais. Uma vez que estes grupos são formados por indivíduos do sexo masculino e feminino, se mostra relevante testar também as hipóteses H2, H3 e H4:

$\mathrm{H} 2$ - Existe diferença entre o comportamento moral masculino do grupo formado por profissionais da área comercial, se comparado ao grupo formado por profissionais de outras áreas - somente amostra masculina.

H3 - Existe diferença entre o comportamento moral feminino do grupo formado por profissionais da área comercial, se comparado ao grupo formado por profissionais de outras áreas - somente amostra feminina.

Os achados de Barnes, Beaulieu e Saxton (2017), mostram que as mulheres são menos tendenciosas ao julgamento moral Utilitarista, isto por estar associado com maior intensidade ao processo decisório cognitivo racional, e menor intensidade aos processos emocionais. Finalizando a análise de gênero, a hipótese $\mathrm{H} 4$ se mostra relevante por comparar o gênero dentro do grupo comercial:

$\mathrm{H} 4$ - Existe diferença entre o comportamento moral masculino e o feminino, dentro do grupo formado por profissionais da área comercial.

O estudo de Zalata et al. (2018), após analisar os relatórios financeiros que foram publicados antes e após a aprovação da lei Sarbanes-Oxley, observou que somente nos CEOs do sexo feminino as ações antiéticas decresceram, enquanto o mesmo não se verificou nas ações dos CEOs do sexo masculino. A última hipótese busca testar se há diferenças no processo decisório por meio do comportamento moral nos profissionais seniores, com idade superior aos cinquenta anos:

H5 - Existe diferença entre o comportamento moral da amostra com idade superior a 50 anos se comparado a amostra com idade entre 19 e 24 anos, dentro do grupo formado por profissionais da área comercial.

Há evidências que apontam na direção de que com o aumento da idade o indivíduo adquire melhor aprendizado holístico e menor tendência ao Utilitarismo, isto conforme os achado de (Worthy, Gorlick, Pachecco, Schyer, \& Maddox, 2011). Corroborando, o estudo Bruin, Parker e Fischhoff (2012), também assegura que com o aumento da idade o indivíduo tem menor tendência ao utilitarismo.

\section{Metodologia}

A presente pesquisa foi submetida à comissão de ética da Pontifícia Universidade Católica de São Paulo - PUCSP, e se encontra aprovada sob o número: CAAE 19048719.4.0000.5482. Os respondentes participantes somente puderam participar da pesquisa após aceitarem o disposto no termo de consentimento livre e esclarecido. O critério de escolha de ambas as amostras foi por acessibilidade e conveniência, e considerou apenas indivíduos a partir dos 18 anos e sem limite de idade, que façam parte do mundo corporativo - independente se na ocasião estavam empregados ou não, ou de quanto tempo atuavam profissionalmente, sem 
distinção de gênero, condição econômica e classe social, e de qualquer parte do território nacional.

A pesquisa considerou duas amostras: amostra presencial e amostra online. A amostra presencial era formada por 47 indivíduos - 32 homens $(68,1 \%)$ e 15 mulheres $(31,9 \%)$. Os participantes foram recrutados em quatro estados do Brasil: 4 indivíduos da Bahia (8,5\%), 1 indivíduo em Minas Gerais (2,1\%), 11 indivíduos em Pernambuco $(23,4 \%)$ e 31 indivíduos em São Paulo (66,0\%). Os participantes presenciais considerados no estudo, possuem entre 20 e 66 anos de idade (média $[\mathrm{M}]=42,35$ anos e desvio padrão [DP] $=11,04$ anos), $\mathrm{e}$ informaram formação educacional, que varia entre ensino médio incompleto e mestrado completo. Já a amostra online era formada por 327 indivíduos - 173 homens (52,9\%), 153 mulheres $(46,8 \%)$ e 1 indivíduo declarou seu sexo como outro $(0,3 \%)$. Os participantes foram recrutados por meio de mídias sociais, e sua localidade no Brasil não foi solicitada. Os participantes online considerados no estudo, possuem entre 18 e 74 anos de idade (média $[\mathrm{M}]=39,60$ anos e desvio padrão $[\mathrm{DP}]=11,84$ anos), e informaram formação educacional, que varia entre ensino médio incompleto e doutorado completo. Como critério adicional e eliminatório, foi aplicado uma questão que avaliava a pessoa no momento do preenchimento e apenas os respondentes que declararam se sentir bem, com pontuação maior ou igual a 5 , foram considerados qualificados. Nesse contexto, apenas um indivíduo foi eliminado da amostra presencial e 16 indivíduos foram eliminados da amostra online. Incluso a isto, mais 4 indivíduos foram eliminados da amostra online, 3 indivíduos que declararam ser menores de 18 anos e 1 indivíduo que declarou seu sexo como outros amostra pequena para ser comparada as demais amostras.

Em relação ao seu objetivo, o procedimento metodológico empregado foi um estudo descritivo de natureza exploratória, utilizando a abordagem mista - qualitativa e quantitativa. Neste sentido, com respeito aos procedimentos técnicos foi realizado uma revisão da literatura no tocante aos quatro principais conceitos subjacentes: GC, ética, dilemas morais e determinantes biológicos do comportamento. Justifica-se a revisão da literatura dos dilemas morais frente ao argumento de Fernandes et al. (2018), que considera que os dilemas morais têm se tornado uma ferramenta eficiente para a pesquisa, análise e entendimento do julgamento moral do indivíduo.

$\mathrm{Na}$ parte experimental, a pesquisa fez uso de um questionário validado e traduzido para o idioma Português Europeu por Fernandes et al. (2018), abordando os dilemas morais, replicado no contexto brasileiro. Este formulário foi validado originalmente por Christensen et al. (2014), que disponibilizou a validação em seis idiomas diferentes, mas não o contemplando em Português. Fernandes et al. (2018), por sua vez, o validaram no idioma, aplicado nesta pesquisa. 
$\mathrm{O}$ estudo original de Fernandes et al. (2018), validou os dilemas morais organizados em três grupos: dilemas pessoais de conflito alto - com 12 dilemas, dilemas pessoais de baixo conflito - com 9 dilemas, e dilemas morais impessoais - com 19 dilemas. Para este estudo, na terceira fase, foi escolhido apenas os 12 dilemas morais pessoais de conflito alto. Esta decisão ocorreu, uma vez que o planejamento contempla aplicar os 12 dilemas para toda a amostra, e aplicar todos os 40 dilemas tornaria a pesquisa extensa e com probabilidade de desistências. Além das características apresentadas, se verificou na validação de Fernandes et al. (2018), que somente a seleção dos dilemas morais pessoais de conflito alto possuem uma boa consistência interna - bom número de Cronbach, na ordem de $\alpha=0.86$. Ainda conforme Fernandes et al. (2018), os demais dilemas formados por: dilemas pessoais de conflito baixo e dilemas impessoais não possuem boa consistência interna - na ordem de $\alpha=0.47$ e $\alpha=0.50$, respectivamente. Cabe ressaltar que os autores fizeram uso do método KR20 test para medirem as três consistências internas. Nesse sentido, cabe ainda mencionar que outro estudo, na mesma direção, fez uso apenas dos dilemas morais de conflito alto, conforme (Laakasuo \& Sundvall, 2017).

Para os participantes da amostra online, após acessar o endereço de internet que direcionava o respondente para a pesquisa, esta iniciava com a apresentação do TCLE. Somente após a leitura e aceite do termo livre e esclarecido, por meio de um clique em uma caixa de seleção, as partes dois e três da pesquisa eram liberadas para preenchimento: Parte dois - Dados demográficos e parte três dilemas morais. O formulário eletrônico versão online foi oferecido por meio da ferramenta gratuita do Google Forms. Já os participantes da mostra presencial, fizeram uso dos fomulários na versão impressa, e somente puderam participar após a leitura e aceite do termo livre e esclarecido. Ambas as versões online ou impressa possuiam o mesmo conteúdo.

Os dilemas morais apresentavam situações hipotéticas ao respondente, pertinente aquele dilema, e ao final de cada um dos 12 dilemas é realizado a seguinte pergunta: "Acha moralmente aceitável...", nesse sentido o respondente deve escolher uma dentre duas opções - as opções possíveis são "sim" ou "não". A resposta "sim", representa que o respondente considera moralmente aceitável, e de forma oposta, a resposta "não", representa que o respondente não considera moralmente aceitável executar a ação. Os casos retratados nos dilemas morais contribuem para a compreensão dos fatores que determinam o julgamento moral do ser humano (Christensen, Flexas, Calabrese, Gut, \& Gomila, 2014). Cada um dos 12 dilemas contribui de forma percentual, ou seja, se um participante responder "não" para todas as perguntas, sua pontuação será 0 (zero), com isso, ele será classificado no limite de moralmente Deontológico. Por sua vez, se um participante 
responder "sim" para todas as perguntas, sua pontuação será 12 (doze), com isso ele será classificado no limite de moralmente Utilitarista. Esta análise permite atribuir uma pontuação compreendida entre 1 e 12 à cada respondente.

As respostas foram transcritas para tabelas de dados no software MS Excel 365, e analisadas pelo próprio software, por meio da ferramenta de análise de variâncias ANOVA. O objetivo da análise de variâncias é o de identificar o comportamento moral Utilitarista e Deontológico, em atendimento as demandas das hipóteses apresentadas neste trabalho.

A partir dos dados coletados, foram estabelecidos e analisados dois grupos para comparação: um grupo formado por profissionais da área comercial, e um segundo grupo formado por profissionais de outras áreas. A escolha do grupo de profissionais da área comercial se justifica frente a uma possível diferença na postura Deontológica deste grupo, em comparação ao outro grupo. Vale lembrar que o comportamento analisado neste trabalho, se refere ao Deontológico e Utilitarista, conforme os estudos de (Greene, Sommerville, Nystrom, Darley, \& Cohen, 2001; Christensen \& Gomila, 2012). Nesse ápice, a atenção na postura Deontológica do grupo da área comercial, se justifica nos achados apresentados na sessão dos dilemas morais, dos pesquisadores Schwepker Jr. e Good (2011), Ojikutu, Obalola e Omoteso (2013), e Zoha (2017), ao relacionar questões que podem influenciar no processo decisório, e no comportamento moral dos profissionais de vendas.

\section{Análise dos resultados}

Para os participantes da amostra online, foi encaminhado um endereço de internet que direcionava o respondente para o formulário eletrônico da pesquisa - que esteve disponível no período de $01 / 07 / 2019$ a 31/08/2019. Os 12 dilemas de conflito alto foram respondidos por 327 indivíduos - 173 homens (52,9\%), 153 mulheres $(46,8 \%)$ e 1 indivíduo declarou seu sexo como outro $(0,3 \%)$. Os participantes foram recrutados por meio de mídias sociais, e sua localidade no Brasil não foi solicitada. Já para a os participantes da amostra presencial, foi agendado data e local para a realização da pesquisa. Os 12 dilemas morais de conflito alto foram respondidos por 47 indivíduos - 32 homens $(68,1 \%)$ e 15 mulheres $(31,9 \%)$. Os participantes foram recrutados em quatro estados do Brasil: 4 indivíduos da Bahia (8,5\%), 1 indivíduo em Minas Gerais (2,1\%), 11 indivíduos em Pernambuco $(23,4 \%)$ e 31 indivíduos em São Paulo (66,0\%).

Para cada respondente foi somado todos os pontos referentes aos dos 12 dilemas morais, e seu valor ajustado numa a escala de 0 a 10 . Nesse sentido pontuações entre 0,00 e 5,00 foram classificadas com o comportamento moral Deontológico, e, portanto, pontuações entre 5,01 e 10,0 foram classificadas com o comportamento moral Utilitarista. Da mesma forma que Fernandes et al. (2018) verificou uma boa consistência interna dos 12 dilemas morais pessoais de conflito alto no processo de 
validação, isto é, encontrou um Cronbach na ordem de $\alpha=0.86$, esta pesquisa também encontrou uma boa consistência interna: $\alpha=$ 0.85 .
A Tabela 1, apresenta a escolaridade dos respondentes da pesquisa - de ambas as amostras: presencial e online.

$\underline{\text { Tabela } 1 \text { - Escolaridade dos participantes - amostra presencial e online }}$

\begin{tabular}{l|c|c|c|c}
\hline \multirow{2}{*}{ Escolaridade dos Respondentes } & \multicolumn{2}{|c|}{ Amostra Presencial } & \multicolumn{2}{c}{ Amostra Online } \\
\cline { 2 - 5 } & Quantidade & Contribuição \% & Quantidade & Contribuição \% \\
\hline Doutorado - completo & & & 13 & $4,20 \%$ \\
\hline Doutorado - incompleto & & & 4 & $1,30 \%$ \\
\hline Mestrado - completo & 3 & $6,50 \%$ & 17 & $5,50 \%$ \\
\hline Mestrado - incompleto & 13 & $28,30 \%$ & 15 & $4,90 \%$ \\
\hline MBA - completo & 6 & $13,00 \%$ & 32 & $10,40 \%$ \\
\hline MBA - incompleto & & & 9 & $2,90 \%$ \\
\hline Pós-graduação - completo & & & 52 & $16,90 \%$ \\
\hline Pós-graduação - incompleto & 2 & $4,30 \%$ & 23 & $7,50 \%$ \\
\hline Superior - completo & 14 & $30,40 \%$ & 82 & $26,70 \%$ \\
\hline Superior - incompleto & 4 & $8,70 \%$ & 45 & $14,70 \%$ \\
\hline Ensino médio - completo & 3 & $6,50 \%$ & 13 & $4,20 \%$ \\
\hline Ensino médio - incompleto & 1 & $2,20 \%$ & 2 & $0,70 \%$ \\
\hline Total & $\mathbf{4 6}$ & $\mathbf{1 0 0 \%}$ & $\mathbf{3 0 7}$ & $\mathbf{1 0 0 \%}$ \\
\hline
\end{tabular}

Fonte: Elaborado pelo autor.

A Tabela 2, apresenta a faixa etária dos respondentes da pesquisa - de ambas as amostras: presencial e online.

Tabela 2 - Faixa etária dos participantes - amostra presencial e online

\begin{tabular}{|c|c|c|c|c|}
\hline \multirow{2}{*}{$\begin{array}{l}\text { Faixa Etária dos } \\
\text { Respondentes }\end{array}$} & \multicolumn{2}{|c|}{ Amostra Presencial } & \multicolumn{2}{|c|}{ Amostra Online } \\
\hline & Quantidade & Contribuição \% & Quantidade & Contribuição \% \\
\hline Entre 18 e 19 anos & & & 1 & $0,30 \%$ \\
\hline Entre 20 e 29 anos & 4 & $8,70 \%$ & 69 & $22,50 \%$ \\
\hline Entre 30 e 39 anos & 14 & $30,40 \%$ & 96 & $31,30 \%$ \\
\hline Entre 40 e 49 anos & 18 & $39,10 \%$ & 79 & $25,70 \%$ \\
\hline Entre 50 e 59 anos & 4 & $8,70 \%$ & 39 & $12,70 \%$ \\
\hline Entre 60 e 69 anos & 6 & $13,00 \%$ & 15 & $4,90 \%$ \\
\hline Entre 70 e 79 anos & & & 4 & $1,30 \%$ \\
\hline Não identificados & & & 4 & $1,30 \%$ \\
\hline Total & 46 & $100 \%$ & 307 & $100 \%$ \\
\hline
\end{tabular}

Fonte: Elaborado pelo autor. 
A Tabela 3 apresenta a distribuição dos respondentes da pesquisa em termos de sexo e área de atuação - de ambas as amostras: presencial e online.

Tabela 3 - Distribuição dos participantes em termos de sexo e área de atuação - amostra presencial e online

\begin{tabular}{|c|c|c|c|c|c|c|}
\hline \multirow{3}{*}{ Sexo } & \multicolumn{3}{|c|}{ Amostra Presencial } & \multicolumn{3}{|c|}{ Amostra Online } \\
\hline & \multicolumn{2}{|c|}{ Área } & \multirow{2}{*}{ Total } & \multicolumn{2}{|c|}{ Área } & \multirow{2}{*}{ Total } \\
\hline & Comercial & Não-comercial & & Comercial & Não-comercial & \\
\hline Feminino & 9 & 6 & 15 & 24 & 117 & 141 \\
\hline Masculino & 10 & 21 & 31 & 34 & 132 & 166 \\
\hline Total & 19 & 27 & 46 & 58 & 249 & 307 \\
\hline
\end{tabular}

Fonte: Elaborado pelo autor.

\subsection{Verificação e testes de hipóteses}

Em síntese, a análise dos dados das hipóteses mostra que há uma diferença significativa entre o comportamento moral masculino e o feminino, dentro do grupo formado por profissionais da área comercial e que também há diferença do comportamento moral nos profissionais com faixa etária entre 50 e 74 anos, entre os grupos comercial e nãocomercial. Contudo, falharam as análises que tentaram identificar diferenças do comportamento moral entre gênero ou comparando a idade mais jovem (19 a 24 anos) com a idade madura (50 a 67 anos).

Da amostra presencial, apenas a hipótese 5 não foi possível se testar, devido a limitação do número de respondentes. Já da amostra online, todas as cinco hipóteses puderam se testar. Comparando-se os resultados das duas amostras, a única divergência se deu na hipótese 4, qual não encontrou diferença no comportamento moral da amostra presencial, mas apresentou diferença de comportamento na amostra online.
H1: Os achados mostram que não há diferença significativa entre o comportamento moral dos indivíduos que formam o grupo comercial se comparados com o grupo nãocomercial. Nesse sentido, rejeita-se a hipótese $\mathrm{H} 1$, com os valores de $\mathrm{P}=0,736$ e $\mathrm{P}=0,632$ para as amostras presencial e online, respectivamente. A amostra presencial contou com 58 indivíduos - 34 homens e 24 mulheres, com idade entre 19 e 67 anos, média $[\mathrm{M}]=37,2$ anos e desvio padrão $\mathrm{DP}=10,6$ anos. $\mathrm{A}$ amostra representada pelo grupo não-comercial era composta por 249 indivíduos - 132 homens e 117 mulheres, com idade entre 18 e 74 anos, média $[\mathrm{M}]=40,2$ anos e desvio padrão $\mathrm{DP}=$ 12,1 anos. Já a amostra online contou com 307 indivíduos, e foi representada pelo grupo comercial composto por 58 indivíduos - 34 homens e 24 mulheres, com idade entre 19 e 67 anos, média $[\mathrm{M}]=37,2$ anos e desvio padrão $\mathrm{DP}=10,6$ anos. A amostra representada pelo grupo não-comercial era composta por 249 indivíduos - 132 homens e 117 mulheres, com 
idade entre 18 e 74 anos, média $[\mathrm{M}]=40,2$ anos e desvio padrão $\mathrm{DP}=12,1$ anos.

H2: Os achados mostram que não há diferença significativa entre o comportamento moral dos indivíduos do sexo masculino que formam o grupo comercial se comparado com o grupo não-comercial. Nesse sentido, rejeita-se a hipótese $\mathrm{H} 2$, com valores de $\mathrm{P}=0,410$ e $\mathrm{P}=0,072$ para as amostras presencial e online, respectivamente. A amostra presencial contou com 31 indivíduos, e foi representada pelo grupo comercial composto por 10 homens, com idade entre 20 e 53 anos, média $[\mathrm{M}]=38,4$ anos e desvio padrão $\mathrm{DP}=9,5$ anos. A amostra representada pelo grupo não-comercial foi composta por 21 homens, com idade entre $23 \mathrm{e}$ 65 anos, média $[\mathrm{M}]=43,3$ anos e desvio padrão DP = 9,9 anos. Já a amostra online contou com 166 indivíduos, e foi representada pelo grupo comercial composto por 34 homens, com idade entre 22 e 67 anos, média $[\mathrm{M}]=38,5$ anos e desvio padrão $\mathrm{DP}=12,5$ anos. $\mathrm{A}$ amostra representada pelo grupo não-comercial era composta por 132 homens, com idade entre 19 e 74 anos, média $[\mathrm{M}]=42,0$ anos e desvio padrão DP $=12,4$ anos. Os resultados das hipóteses 1 e 2, contrapõe-se aos estudos de Zoha (2017) e Chen (2019) que encontraram diferenças no comportamento moral de equipes comerciais.

H3: Os achados mostram que não há diferença significativa entre o comportamento moral dos indivíduos do sexo feminino que formam o grupo comercial se comparados com o grupo não-comercial. Nesse sentido, rejeita-se a hipótese $\mathrm{H} 3$, com valores de $\mathrm{P}=0,589$ e $\mathrm{P}=0,117$ para as amostras presencial e online, respectivamente. A amostra presencial contou com 15 indivíduos, e foi representada pelo grupo comercial composto por 9 mulheres, com idade entre 30 e 62 anos, média $[M]=43,6$ anos e desvio padrão $\mathrm{DP}=12,0$ anos. $\mathrm{A}$ amostra representada pelo grupo não-comercial foi composta por 6 mulheres, com idade entre 23 e 66 anos, média $[\mathrm{M}]=43,8$ anos e desvio padrão $\mathrm{DP}=16,6$ anos. Já a amostra online contou com 141 indivíduos, e foi representada pelo grupo comercial composto por 24 mulheres, com idade entre 19 e 47 anos, média $[\mathrm{M}]=35,5$ anos e desvio padrão $\mathrm{DP}=7,1$ anos. A amostra representada pelo grupo nãocomercial era composta por 117 mulheres, com idade entre 18 e 69 anos, média $[\mathrm{M}]=38,1$ anos e desvio padrão $\mathrm{DP}=11,4$ anos.

H4: Os achados mostram que há dois achados distintos, uma vez que a amostra presencial não encontrou diferença significativa entre o comportamento moral masculino e o feminino, dentro do grupo formado por profissionais da área comercial, contudo a amostra online encontrou diferença significativa entre o gênero masculino $e$ feminino. Nesse sentido, rejeita-se a hipótese H4 para a amostra presencial, e não se rejeita a hipótese h4 para a amostra online, com valores de $\mathrm{P}=0,217$ e $\mathrm{P}=0,002$ para as amostras presencial e online, respectivamente. A amostra presencial do grupo comercial contou com 19 indivíduos, e foi representada por 9 mulheres, com idade entre 30 e 62 anos, média $[\mathrm{M}]=43,6$ 
anos e desvio padrão $\mathrm{DP}=12,0$ anos. $\mathrm{A}$ amostra masculina foi composta por 10 homens, com idade entre 20 e 53 anos, média $[\mathrm{M}]=38,4$ anos e desvio padrão DP $=9,5$ anos . Já a amostra online do grupo comercial contou com 58 indivíduos, e foi representada por 24 mulheres, com idade entre 19 e 47 anos, média $[\mathrm{M}]=35,5$ anos e desvio padrão $\mathrm{DP}=7,1$ anos. A amostra masculina foi composta por 34 homens, com idade entre 22 e 67 anos, média $[\mathrm{M}]=38,5$ anos e desvio padrão $\mathrm{DP}=12,5$ anos. $\mathrm{O}$ achado da amostra presencial corrobora com o estudo de (Greene, Morelli, Lowenberg, Nystrom, \& Cohen, 2008), que preconiza que o sexo, idade, afiliação política e crença religiosa não conseguem explicar de forma significativa as diferenças de comportamento, contudo o achado da amostra online corrobora com o estudo de (Arutyunova, Alexandrov, \& Hauser, 2016) que identificou que o homem possui tendência mais Utilitarista do que a mulher supostamente em decorrência da maior emocionalidade nas relações interpessoais das mulheres.

Ainda que não fizesse parte do trabalho, somente como curiosidade e informação adicional, foi realizado a mesma análise da hipótese H4 para o grupo não-comercial. Diferentemente dos achados no grupo comercial, nas amostras presencial e online do grupo não-comercial não foi encontrado diferença significativa de comportamento, com valores de $\mathrm{P}=0,954$ e $\mathrm{P}=0,499$ para as amostras presencial e online, respectivamente.
Devido a limitação do número de respondentes, a hipótese 5 pode ser testada apenas para a amostra online.

H5: Os achados mostram que não há diferença significativa de comportamento entre as faixas etárias propostas dentro do grupo comercial. Nesse sentido, rejeita-se a hipótese $\mathrm{H}$, com valor-P=0,478. A amostra do grupo comercial contou com 13 indivíduos organizados em duas faixas etárias. A primeira faixa etária foi representada por 6 indivíduos com idade entre 19 e 24 anos, média $[\mathrm{M}]=$ 22,17 anos e desvio padrão $\mathrm{DP}=0,84$ anos. $\mathrm{A}$ segunda faixa etária foi representada por 7 indivíduos com idade entre 50 e 67 anos, média $[\mathrm{M}]=57,71$ anos e desvio padrão $\mathrm{DP}=6,52$ anos. Ainda que os estudos de Bruin, Parker, \& Fischhoff (2012) ou Sparrow \& Spaniol (2016), indiquem que a idade madura (50 e 67 anos) possua melhor capacidade analítica para a tomada de decisão se comparado a idade jovem $(19$ e 24 anos) com características Deontológicas, a hipótese 5 não conseguiu corroborar, identificando possíveis diferenças Utilitarista e Deontológica entre os grupos.

Ainda que não fizesse parte deste trabalho, somente como curiosidade e informação adicional, foram realizadas duas análises complementares com o objetivo de investigar mais sobre a faixa etária superior aos 50 anos. A primeira análise adicional, reproduziu a análise realizada para a hipótese H5, contudo não se limitou ao grupo comercial, nesta analise se considerou ambas as amostras do grupo comercial e do grupo não-comercial. 
Foram analisados 77 indivíduos - 19 indivíduos na faixa etária entre 18 e 24 anos e 58 indivíduos na faixa etária entre 50 e 74 anos. A análise encontrou as medias de 4,25 e 3,26respectivamente para 18 e 24 anos, e 50 e 74 anos, bem como o valor-P=0,181. Nesse sentido, de igual modo da análise original da hipótese $\mathrm{H} 5$, rejeita-se a hipótese do primeiro estudo adicional de H5 para a amostra.

A segunda análise adicional comparou os indivíduos do grupo comercial com faixa etária entre 50 e 74 anos, com os indivíduos do grupo não-comercial com a mesma faixa. Foram analisados 58 indivíduos -7 indivíduos do grupo comercial e 51 indivíduos do grupo não-comercial. A análise encontrou as medias de 5,95 e 2,89-respectivamente para os grupos comercial e não-comercial, bem como o valor$\mathrm{P}=0,008$. Nesse sentido, os dados mostram que há diferença entre grupos - grupo comercial orientado ao comportamento moral Utilitarista e grupo não-comercial orientado ao comportamento moral Deontológico, considerando-se a faixa etária de 50 e 74 anos. Nesse ápice, não se rejeita a hipótese do segundo estudo adicional de $\mathrm{H} 5$ para a amostra.

Observando-se as médias das duas análises adicionais da hipótese 5, verifica-se uma tendência Deontológica da amostra madura (50 e 74 anos) se comparado a idade jovem (18 e 24 anos) de ambos os grupos, e a amostra da idade madura do grupo não-comercial é orientado a Deontologia, enquanto a amostra madura do grupo comercial é orientado ao comportamento Utilitarista.

\section{Considerações finais}

A presente pesquisa aborda um tema emergente, ainda não totalmente compreendido e com uma lacuna do conhecimento científico na área. Nesse sentido, é necessário que a governança corporativa possa refletir, acompanhe com políticas e instrumentos próprios, e compreenda estes efeitos e seus avanços científicos. Cabe reforçar que fundamentos com base cientifica possuem naturalmente força de convencimento, e se estes aspectos não estiverem adequadamente validados, decorre que a aplicação indevida dos aspectos do comportamento humano não permitirá compreender os processos do julgamento moral - tais como o comportamento segregacionista e o comportamento preconcebido.

Seja na academia ou nas organizações, a literatura e os códigos de conduta não contemplam possíveis indícios relacionados aos fatores biológicos nos aspectos do comportamento humano no processo decisório. Tanto o IBGC ou outra normativa, não abordam as questões biológicas do comportamento que possam afetar o julgamento moral, que por sua vez poderá influenciar no comportamento ético organizacional. As boas práticas de GC partem da premissa que todos são iguais e não preconiza que haja tratamento diferenciado para pessoas que possam ser diferentes. Ora, se a ética pode ser determinada pelo julgamento moral, assim como mostra esta pesquisa, isto poderá trazer um grande reflexo nas organizações, reforçando a importância da GC 
em criar os seus mecanismos de reflexão e de acompanhamento.

Com base no referencial teórico, foi possível verificar que o processo decisório pode ser influenciado por fatores genéticos, sociais e biossociais, contudo, nota-se com base em diversos achados de estudos empíricos, que a potencialidade desta influência e seus limites, ainda não são totalmente compreendidos, haja visto que há estudos semelhantes com resultados semelhantes, mas há estudos semelhantes com resultados divergentes.

A análise dos dados de campo, fez uso de um questionário validado e encontrou achados importantes. Alguns desses achados corroboram com a literatura, enquanto outros se opõem a achados de outros estudos. À exemplo disso, a hipótese H1, não conseguiu verificar que os profissionais da área comercial são orientados ao julgamento moral Utilitarista. A hipótese $\mathrm{H} 2$, falhou ao procurar diferenças no julgamento moral masculino do grupo comercial comparado ao grupo não-comercial de igual modo a hipótese H3 também falhou ao procurar diferenças no julgamento moral feminino entre ambos os grupos. Já a hipótese H4, permitiu uma provocação, ao apresentar dois resultados diferentes - dentro do grupo comercial, o comportamento masculino não difere significativamente do feminino para a amostra presencial, mas contradizendo este resultado, se trocarmos a amostra pela amostra online, verifica-se que os comportamentos diferem entre si. Por fim, ainda que a hipótese H5 não tenha encontrado diferença significativa de comportamento na amostra com idade acima dos 50 anos se comparada com uma amostra mais jovem, um segundo estudo foi aplicado e verificou-se que há diferença significativa entre as amostras do grupo comercial com a do grupo não-comercial - ambos com idade acima dos 50 anos.

Constata-se que dentro do grupo comercial, o sexo masculino tem maior tendência ao julgamento moral Utilitarista, enquanto o sexo feminino tem maior tendência a Deontologia. Nesse ponto, com base nos achados, é possível afirmar que este estudo não é conclusivo, e novos estudos precisam ser conduzidos - novas hipóteses necessitam ser propostas. Nesse contexto, a análise do referencial teórico e os dados extraídos da análise dos resultados, impulsionaram a formulação de novas hipóteses, sugere-se:

- Com o aumento da idade, o indivíduo alcança melhor capacidade analítica em contextos em que é preciso aprender com os erros e acertos de escolhas anteriores independente da área de atuação e do sexo. $\mathrm{O}$ indivíduo alcança um melhor desempenho estratégico, uma vez que não há redução na aversão ao risco.

- O homem possui tendência mais Utilitarista se comparado a mulher, baseado na premissa de que tal diferença seja decorrente da maior emocionalidade nas relações interpessoais das mulheres. A mulher possui maior aversão ao risco, se comparado ao sexo masculino. 
- Vendedores com o comportamento moral Deontológico possuem melhores resultados, se comparados a vendedores com o comportamento moral Utilitarista.

- Profissionais que recebem salários fixos, os chamados mensalistas, possuem comportamento moral mais Deontológico, se comparado a profissionais que recebem salários baseados em resultados.

Em termos de limitações, destaca-se a utilização de amostras por conveniência e o tamanho da amostra na pesquisa. Espera-se que os resultados apresentados abram novos caminhos de trabalhos futuros frente às questões ainda não totalmente compreendidas no campo da governança corporativa.

\section{Referências}

Arutyunova, K. R., Alexandrov, Y. I., \& Hauser, M. D. (5 de Set. de 2016). Sociocultural Influences on Moral Judgments: East-West, Male-Female, and Young-Old. Frontiers in Psychology, 7| Article 1334, pp. 1-15.

Asanuma, W. (2010). A Deontological Approach to Business Ethics: Beyond Maximization of Profits. The International Journal of the Humanities, 8(2), 245-253.

Ashley, P. A. (2005). Ética e responsabilidade social nos negócios (2 ${ }^{\mathrm{a}}$ ed.). São Paulo: Saraiva.

Barbieri, D., \& Pilati, R. (jul./set. de 2018). Julgamento Moral do Aborto: Influência da Atitude Prévia, Princípios Deontológicos e Utilitaristas. Psico-USF, 23(3), 527-537.

Barnes, T. D., Beaulieu, E., \& Saxton, G. W. (18 de Jan. de 2017). Restoring trust in the police: Why female officers reduce suspicions of corruption. Wiley Governance, 31, pp. 143-161.
Baumgarten, F. (1954). O caráter e a psicologia. Arquivos Brasileiros de Psicologia, 6(3), 5363.

Bizerra, A. V., Alves, F. d., \& Ribeiro, C. d. (Nov. de 2012). Governança pública: uma proposta de conteúdo mínimo para os relatórios de gestão das entidades governamentais. EnAPG/ANPAD - Encontro de Administração Pública e Governo, 1-16.

Bostyn, D. H., Sevenhant, S., \& Roets, A. (2018). Of Mice, Men, and Trolleys: Hypothetical Judgment Versus Real-Life Behavior in Trolley-Style Moral Dilemmas. APS - Association of Psychological Science, 1-10.

Brasil. (1984). Lei 7.209. Acesso em 09 de Maio de 2019, disponível em Presidencia da República - Casa Civil: http://www.planalto.gov.br/ccivil_03/leis/19 80-1988/17209.htm

Brasil. (2002). Lei 10.406. Acesso em 06 de Maio de 2019, disponível em Presidencia da República - Casa Civil: http://www.planalto.gov.br/ccivil_03/leis/20 02/110406.htm

Brasil. (2009). Lei Complementar 131. Acesso em 05 de Maio de 2019, disponível em Presidencia da República - Casa Civil: http://www.planalto.gov.br/ccivil_03/leis/lcp /lcp131.htm

Brasil. (2011). Lei 12.527. Acesso em 05 de Maio de 2019, disponível em Presidencia da República - Casa Civil: http://www.planalto.gov.br/ccivil_03/_ato20 11-2014/2011/lei/112527.htm

Bruin, W. B., Parker, A. M., \& Fischhoff, B. (Set. de 2012). Explaining Adult Age Differences in Decision-making Competence. Journal of Behavioral Decision Making, 25(4), 1-14.

Chen, D. L. (9 de Fev. de 2019). Markets and Morality: Do Free Markets Corrode Moral Values? TSE Working Paper No. 16-692, pp. $1-64$.

Christensen, J. F., \& Gomila, A. (2012). Moral dilemmas in cognitive neuroscience of moral decision-making: A principled review. Neuroscience and Biobehavioral Reviews, 36, pp. 1249-1264.

Christensen, J. F., Flexas, A., Calabrese, M., Gut, N. K., \& Gomila, A. (2014). Moral judgment reloaded: a moral dilemma 
validation study. Frontiers in Psychology Emotion Science, 1-18.

Corvo, K. (2019). Early-life risk for domestic violence perpetration: Implicationsfor practice and policy. Infant Mental Health Journal, 40, pp. 152-164.

Crockett, M. (2018). Modelos de Moralidade. Revista Brasileira de Políticas Públicas, 8(2), 143-152.

Cuñat-Agut, M., Martí-Vilar, M., \& Suay I, F. L. (Jun. de 2016). Brain structures involved in moral reasoning: a review. The International Journal of Psychosocial and Cultural Genomics, Consciousness \& Health Research, 2(II), 38-44.

CVM. (11 de Dez. de 2008). Deliberação CVM 560. (C. d.-C. CVM, Editor, C. d.-C. CVM, Produtor, \& CVM, Comissão de Valores Mobiliários - CVM) Acesso em 05 de Maio de 2019, disponível em CVM, Comissão de Valores Mobiliários - CVM:

http://www.cvm.gov.br/legislacao/deliberaco es/deli0500/deli560.html

CVM. (07 de Dez. de 2009). Deliberação CVM 586. Fonte: CVM, Comissão de Valores Mobiliários - CVM:

http://www.cvm.gov.br/legislacao/instrucoes/ inst586.html

CVM. (2009). Instrução CVM 480. Acesso em 05 de Maio de 2019, disponível em CVM, Comissão de Valores Mobiliários - CVM: http://www.cvm.gov.br/legislacao/instrucoes/ inst $480 . \mathrm{html}$

Decety, J., \& Cowell, J. M. (09 de Mar. de 2016). Our Brains are Wired for Morality: Evolution, Development, and Neuroscience. (P. Glimcher, Editor) Acesso em 26 de Set. de 2019, disponível em Frontiers for Young Minds: https://kids.frontiersin.org/article/10.3389/fry m.2016.00003\#

Denson, T. F., O'Dean, S. M., Blake, K. R., \& Beames, J. R. (Maio de 2018). ggression in Women: Behavior, Brain and Hormones. Frontiers in Behavioral Neuroscience, 12(81), 1-20.

DPIC. (2019). $2019 \mid$ Death Penalty

Information Center. Acesso em 05 de Out. de 2019, disponível em DPIC | Death Penalty Information Center: https://deathpenaltyinfo.org/executions/2019
Durkheim, É. (2012). A educação moral / Émile Durkheim; tradução de Raquel Weiss (2a ed.). Petrópolis, RJ: Vozes.

Egorov, E. E., Lebedeva, T. E., Bulganina, S. V., \& Vasilyeva, L. I. (2015). Some Aspects of the Implementation of the Principle of Transparency in Russian Universities: Research, Experience, Perspectives. International Education Studies, 8(5). doi:doi:10.5539/ies.v8n5p191

Elqayam, S., Wilkinson, M. R., Thompson, V. A., Over, D. E., \& Evans, J. S. (Jun. de 2017). Utilitarian Moral Judgment Exclusively Coheres with Inference from Is to Ought. Frontiers in Psychology, 8(Artigo 1042), 1-18.

Farrington, D. P., Kazemian, L., \& Piquero, A. R. (2019). The Oxford Handbook of Developmental and Life-Course Criminology. New York, USA: Oxford University Press.

FBI. (2019). White-Collar Crime - FBI. Acesso em 05 de Out. de 2019, disponível em Welcome FBI.gov - FBI: https://www.fbi.gov/investigate/white-collarcrime

Fernandes, C., Gonçalves, A. R., Pasion, R., Ferreira-Santos, F., Paiva, T. O., Castro, J. M., ... Marques-Teixeira, J. (2018). European Portuguese adaptation and validation of dilemmas used to assess moral decision-making. Trends Psychiatry Psychother, 40(1), pp. 38-46.

Gawronski , B., \& Beer, J. S. (2017). What makes moral dilemma judgments "utilitarian" or "deontological"? Social Neuroscience, 12(6), 626-632.

Gouveia, V. V. (out./dez. de 2015). Psicologia Social como Ciência e Prática: O que Pensam Pesquisadores Brasileiros? Psicologia: Teoria e Pesquisa, 31(4), 491500.

Greco, R. (2015). Curso de Direito Penal Parte Geral - Artigos $1^{\circ}$ a 120 do Código Penal (17 $7^{\mathrm{a}}$ ed., Vol. I). Niterói, RJ: Impetus.

Greene, J. D., Morelli, S. A., Lowenberg, K., Nystrom, L. E., \& Cohen, J. D. (Jun. de 2008). Cognitive load selectively interferes with utilitarian moral judgment. Cognition, 107(3), pp. 1144-1154.

Greene, J. D., Sommerville, R. B., Nystrom, L. E., Darley, J. M., \& Cohen, J. D. (2001). An fMRI Investigation of Emotional 
Engagement in Moral Judgment. Science, 293, pp. 2105-8.

Greene, J., Nystrom, L., Engell, A., Darley, J., $\&$ Cohen, J. (2004). The neural basis of cognitive conflict and control in moral judgment. Neuron, 44, pp. 389-400.

Healey, M. P., Hodgkinson, G. P., \& Massaro, S. (2018). Chapter 2 Can Brains Manage?

The Brain, Emotion, and Cognition in Organizations. Em L. Petitta, C. E. Härtel, N. M. Ashkanasy, W. J. Zerbe, \& E. P. Limited (Ed.), Research on Emotion in Organizations, Volume 14: New Ways of Studying Emotions in Organizations (pp. 2758). Emerald Publishing Limited.

IBGC. (2015). Código das Melhores Práticas de Governança Corporativa (5 $5^{\mathrm{a}} \mathrm{ed}$.). (I. B. Corporativa, Ed.) São Paulo: Instituto Brasileiro de Governança Corporativa.

IBGC. (2017). Compliance à Luz da Governança Corporativa. (I. B. Corporativa, Ed.) São Paulo: Instituto Brasileiro de Governança Corporativa.

Kahane, G., Everett, J. A., Earp, B. D., Farias, M., \& Savulescu, J. (2015). 'Utilitarian' judgments in sacrificial moral dilemmas do not reflect impartial concern for the greater good. Cognition, pp. 193-209.

Laakasuo, M., \& Sundvall, J. (Ago de 2017). Are Utilitarian/Deontological Preferences Unidimensional? Frontiers in Psychology, 7(Artigo 1228), 1-18.

Mednick, S. A., \& Kandel, E. (1988). Genetic and Perinatal Factors in Violence. Em T. E. Moffitt, S. A. Mednick, \& Springer (Ed.), Biological Contributions to Crime Causation (Vol. 40, pp. 121-131). Dordrecht: NATO ASI Series (Series D: Behavioural and Social Sciences). Springer.

Micewski, E. R., \& Troy, C. (Abr. de 2007). Business Ethics - Deontologically Revisited. Journal of Business Ethics, 72(1), 17-25.

Mill, J. S. (2005). Utilitarismo: Introdução, tradução e notas de Pedro Galvão. Porto: Porto Editora.

Moll, J., Oliveira-Souza, R. d., Basilio, R., Bramati, I. E., Gordon, B., Rodríguez-Nieto, G., . . Grafman, J. (2018). Altruistic decisions following penetrating traumatic brain injury. Brain: A Journal of Neurology, pp. 1-12.

Moore, A. B., Clark, B. A., \& Kane, M. J. (Jul. de 2008). Who shalt not kill? Individual dif- ferences in working memory capacity, executive control, and moral judgment. Psychological Science, 19(6), pp. 549-557.

Ojikutu, R. K., Obalola, M. A., \& Omoteso, K. (2013). Assessing the Relationship between Sales Quotas and Moral Judgement of Insurance Salespersons: The Moderating Effects of Personal Moral Values, Quota Failure Consequences, and Corporate Ethical Climate. Journal of Emerging Trends in Economics and Management Sciences, 4(2), pp. 274-288.

Oliveira, C. (2015). O Utilitarismo em John Stuart Mill. Dissertatio Revista de Filosofia, 41, 11-29.

Oliveira, M. M., Medeiros, M. A., Silva, R. L., \& Lucas, G. A. (dez. de 2016). Desenvolvimento Sustentável nas Organizações como Oportunidade de Novos Negócios. Revista Valore, 1(1), 42-46.

Pascual, L., Rodrigues, P., \& Gallardo-Pujol, D. (Set. de 2013). How does morality work in the brain? A functional and structural perspective of moral behavior. Frontiers in Integrative Neuroscience, 7(Artigo 65), 1-8.

Pedrosa, J. (2015). Pensamentos Edificantes. Natal: Clube dos Autores.

Picon, R. (2015). Diferença entre dolo eventual e culpa consciente - Jus.com.br|Jus Navigandi. Acesso em 09 de Maio de 2019, disponível em JUS.com.br: https://jus.com.br/artigos/38268/diferencaentre-dolo-eventual-e-culpa-consciente

Portnoy, J., Legee, K., Raine, A., Choy, O., \& Rudo-Hutt, A. S. (2018). Biosocial Risk Factors for Academic Dishonesty: Testing a New Mediation Model in Young Adults. Journal of Contemporary Criminal Justice, pp. 1-15.

Raine, A. (2015). A Anatomia da Violência; as raízes biológicas da criminalidade / Adrian Raine; tradução: Maiza Ritomy Ite; revisão técnica: Ney Fayet Júnior, Pedro Antônio Schmidt do Prado-Lima. Porto Alegre: Artmed.

Rossetti, J. P., \& Andrade, A. (2016). Governança Corporativa: Fundamentos, Desenvolvimento e Tendências $\left(7^{\mathrm{a}} \mathrm{ed}\right.$.). São Paulo: Atlas.

Schwepker Jr., C. H., \& Good, D. J. (2011). Moral Judgment and its Impact on Businessto-Business Sales Performance and Customer 
Relationships. Journal of Business Ethics, 98, pp. 609-625.

Silva, E. C. (2018). Governança Corporativa nas Empresas: guia prático de orientação para acionistas, investidores, conselheiros de administração e fiscal, auditores, executivos, gestores, analistas de mercado e pesquisadores ( $4^{\mathrm{a}}$ ed.). São Paulo: Atlas.

Silveira, A. D. (2010). Governança Corporativa no Brasil e no Mundo: teoria e prática ( $2^{\mathrm{a}}$ ed.). Rio de Janeiro: Elsevier.

Sison, J. A., Ferrero, I., \& Guitián, G. (2018). Business Ethics: A Virtue Ethics and Common Good Approach. (T. \&. Group, Ed.) Routledge.

Sparrow, E. P., \& Spaniol, J. (Set. de 2016). Age-Related Changes in Decision Making. Current Behavioral Neuroscience Reports Springer, 3(4), 285-292.

Staveren, I. V. (Jan. de 2007). Beyond Utilitarianism and Deontology: Ethics in
Economics. Review of Political Economy, 19(1), 21-35.

Todorov, J. C. (fev. de 2013). Sobre uma definição de comportamento. Perpectivas em Análise do Comportamento, 3(1), 032-037.

Tricker, R. I. (2015). Corporate Governance: Principles, Policies, and Practices ( $3^{\mathrm{a}}$ ed.). Londres: Oxford University Press.

Worthy, D. A., Gorlick, M. A., Pachecco, J. L., Schyer, D. M., \& Maddox, W. T. (Nov. de 2011). With Age Comes Wisdom: DecisionMaking in Younger and Older Adults. Psychology Science, 22(11), 1375-1380.

Zalata, A. M., Ntim, C., Aboud, A., \& Gyapong, E. (24 de Maio de 2018). Female CEOs and Core Earnings Quality: New Evidence on the Ethics Versus RiskAversion Puzzle. Journal of Business Ethics, pp. 1-20.

Zoha, F. (Jan.-Jun. de 2017). Salesforce Ethical Behaviour: A Control System Perspective. Journal of Marketing Vistas, 7(1), pp. 68-75. 